\title{
Chemical Control of Sand Sagebrush: Implications for Lesser Prairie-Chicken Habitat
}

\author{
Eric T. Thacker, ${ }^{1}$ Robert L. Gillen, ${ }^{2}$ Stacey A. Gunter, ${ }^{3}$ and Tim L. Springer ${ }^{4}$ \\ Authors are ${ }^{1}$ Rangeland Ecologist, ${ }^{3}$ Animal Scientist, and ${ }^{4}$ Research Agronomist, Southern Plains Range Research Station, USDA-ARS, Woodward, OK \\ 73801, USA; and 2 Department Head, Western Kansas Agricultural Research Center, Hays, KS 67601, USA.
}

\begin{abstract}
Traditional management of sand sagebrush (Artemisia filifolia) rangelands has emphasized sagebrush control to increase forage for livestock. Since the 1950s shrub removal has been primarily achieved with herbicides. Concerns over declining lesser prairiechicken (Tympanuchus pallidicinctus; LPC) populations have led to increased scrutiny over the use of herbicides to control shrubs. The objective of our research was to describe changes to LPC habitat qualities following chemical control of sand sagebrush in northwest Oklahoma. Study pastures ranged in size from 10 to 21 ha. Five pastures were sprayed with 2,4dichlorophenoxyacetic acid (2,4-D) in 2003 (RECENT), five were sprayed with 2,4-D in 1984 (OLD), and four received no treatment (SAGE). We measured habitat structure (sagebrush cover, sagebrush density, visual obstruction [VO], and basal grass cover), and dietary resources (forb density, forb richness, and grasshopper density) in all pastures from 2003 to 2006. OLD and RECENT pastures had less sagebrush (cover and density) and VO than SAGE pastures. OLD pastures produced more annual forbs than either SAGE or RECENT pastures. SAGE pastures had more perennial forbs than RECENT pastures. Herbicide application reduced protective cover while providing no increase in forb abundance in RECENT pastures. Our results indicated that it may take several years to realize increases in annual forbs following application of 2,4-D. However, loss of protective cover may persist for multiple years $(20+\mathrm{yr})$, and removal of sagebrush did not increase forb richness or grasshopper abundance. Thus, 2,4-D may have limited use as a habitat management tool because it takes numerous years to reap the benefit of increased forb abundance while reducing habitat structure in the long term.
\end{abstract}

\section{Resumen}

El manejo tradicional de pastizales de artemisa (Artemisia filifolia) ha enfatizado el control de artemisa para aumentar el forraje para el ganado. Desde los 1950s la remoción de arbustivas ha sido lograda principalmente con herbicidas. La preocupación por la disminución de las poblaciones de gallinas de pradera (Tympanuchus pallidicinctus; LPC) ha llevado a aumentar la vigilancia sobre el uso de herbicidas para el control de arbustivas. El objetivo de nuestra investigación fue describir los cambios en la calidad del hábitat de LPC después de controles químicos de Artemisia filifolia en el noroeste de Oklahoma. Los potreros en estudio variaron en tamaño de 10 a 21 ha. Cinco potreros fueron asperjados con 2,4-acido diclorofenoxiacético (2,4-D) en 2003 (RECIENTE), otros cinco fueron asperjados con 2,4-D en 1984 (VIEJO) y cuatro no recibieron tratamiento (ARTEMISA). Medimos la estructura del hábitat (cobertura y densidad de artemisa, obstrucción visual [OV] y cobertura basal de pastos) y fuentes de dieta (densidad y riqueza de hierbas y densidad de chapulines) en todos los potreros de 2003 a 2006. Potreros VIEJO Y RECIENTE tuvieron menos artemisa (cobertura y densidad) y OV que los potreros ARTEMISA. Los porteros VIEJO produjeron más hierbas anuales los porteros ARTEMISA Y RECIENTE. Los potreros ARTEMISA tuvieron más hierbas perennes que los potreros RECIENTE. La aplicación de herbicida reduce la cubierta protectora mientras que no aumenta la abundancia de hierbas en los potreros RECIENTE. Nuestros resultados indican que puede tomar varios años el lograr incrementar las hierbas anuales después de la aplicación de 2,4-D. Sin embargo, la pérdida de cubierta protectora podrá mantenerse por múltiples años (20+ años) y el remover la artemisa no aumenta la riqueza de hierbas y abundancia de chapulines. Entonces, 2,4-D podrá tener uso limitado como herramienta de manejo de hábitat porque toma muchos años obtener el beneficio de aumentar la abundancia de hierbas mientras que se reduce la estructura del hábitat en el largo plazo.

Key Words: Artemisia filifolia, habitat management, mixed prairie, shrub control

\section{INTRODUCTION}

Lesser prairie-chickens (Tympanuchus pallidicinctus; LPC) are endemic to the grasslands of the southern Great Plains (Hagen and Giesen 2005). LPC populations have been declining for several decades (Crawford 1980; Taylor and Guthery 1980),

Research was funded through the Southern Plains Range Research Station, USDA-ARS, Woodward, OK 73801.

Correspondence: Eric Thacker, Southern Plains Range Research Station, USDA-ARS, Woodward, OK 73801, USA. Email: eric.thacker@ars.usda.gov

Manuscript received 6 September 2011; manuscript accepted 8 June 2012. and have been designated as a "candidate species" by the Fish and Wildlife Service. The declines of LPC have been commonly attributed to direct loss of habitat through cultivation (Crawford and Bolen 1976; Taylor and Guthery 1980; Fuhlendorf et al. 2002), and the remaining habitat has been compromised by improper livestock grazing, brush control, tree encroachment, and fragmentation due to energy development (Jackson and DeArment 1963; Crawford 1980; Mote et al. 1999; Fuhlendorf et al. 2002; Hagen et al. 2004). It has been estimated that greater than $90 \%$ of former LPC habitat has been lost (Mote et al. 1999), and the remaining 
habitat is threatened by degradation (Jackson and DeArment 1963; Jones 1963; Giesen 1994; Fuhlendorf et al. 2002; Hagen et al. 2004; Robb and Schroeder 2005). This highlights the need to ensure that remaining habitat is carefully managed to ensure that LPC populations persist in occupied portions of their former range.

Improper livestock grazing has contributed to habitat degradation; however, livestock grazing can have indirect impacts on LPC habitat and populations (Hamerstrom and Hamerstrom 1961; Woodward et al. 2001). It has been suggested that one indirect consequence of livestock grazing on prairie grouse habitat is that shrubs are often removed to increase forage production for livestock (Beck and Mitchell 2000). Traditionally range managers used herbicides, mechanical practices, and fire to control shrubs and increase forage for livestock (Mcllvain and Savage 1949; Valentine 1980). 2,4dichlorophenoxyacetic acid (2,4-D) has been the herbicide most commonly used for controlling sand sagebrush (Artemisia filifolia Torr.; Allred 1949; McIlvain and Savage 1949). Application of 2,4-D was recommended as a management technique to increase grazing capacity by increasing available forage for livestock (McIlvain and Savage 1954). Use of 2,4-D gained popularity because it was an inexpensive and simple technique to control shrubs. Even though the use of 2,4-D has been in practice for nearly $70 \mathrm{yr}$, there is little evidence in the peer-reviewed literature to suggest sand sagebrush control increases cattle gain $\cdot$ animal $^{-1}$ or that it will increase financial returns without increasing stocking rates. It has been suggested that shrub removal increases grass abundance, thereby allowing for increases in the number of animals grazing treated rangelands, thus increasing cattle gains $\cdot \mathrm{ha}^{-1}$ (Mcllvain and Savage 1954; Sims and Gillen 1999; Gunter et al. 2012).

LPC rely on shrubs such as sand sagebrush, sumac (Rhus spp. L.), and sand shinnery oak (Quercus harvardii Rybd.; Copelin 1963; Jackson and DeArment 1963; Jones 1963; Cannon and Knopf 1981; Giesen 1994), for thermal cover, nesting cover, escape cover, and food (Jones 1963; Giesen 1994; Patten et al. 2005; Pitman et al. 2005; Bell et al. 2010). Evidence has shown that LPC populations have been negatively impacted by shrub control (Jackson and DeArment 1963; Crawford 1980). Conversely, some have proposed that shrub densities have increased to a point that they are limiting herbaceous productivity in the associated plant community (Mcllvain and Savage 1954). Therefore, conclusions like this have led to speculation that wildlife may profit from shrub control projects. Some have suggested that modest levels of brush control may benefit LPC because shrub control may increase grass and forbs important to LPC (Donaldson 1969). Hagen et al. (2004) proposed that research is needed to determine impacts of chemical treatments on forb production and richness.

Research documenting the effects of 2,4-D application on LPC habitat has not been adequately investigated (Hagen et al. 2005). Therefore, our objective is to describe changes in LPC habitat structure and dietary resources after application of 2,4$\mathrm{D}$ in a sand sagebrush-mixed prairie. This research will help to determine if reduction of sand sagebrush increases forb abundance and species richness, thereby increasing dietary resources for LPC.

\section{METHODS}

The study was conducted in a sand sagebrush-mixed prairie (Berg 1994) at the USDA-ARS Southern Plains Experimental Range north of Fort Supply, Oklahoma (lat $36^{\circ} 35^{\prime} \mathrm{N}$, long $\left.99^{\circ} 35^{\prime} \mathrm{W}\right)$. The elevation of the study area was $644 \mathrm{~m}$. The area is characterized by mild dry winters $\left(3.3^{\circ} \mathrm{C}\right.$ and $56.1 \mathrm{~mm}$ moisture) and warm semiarid summers $\left(25.6^{\circ} \mathrm{C}\right.$ and $222.1 \mathrm{~mm}$ moisture). The area receives a total of $510 \mathrm{~mm}$ of precipitation annually, $70 \%$ of which falls during the spring and summer. Soils consist of Pratt series (sandy, mixed, mesic Psammantic Haplustalfs) on lower slopes and level areas and Tivoli series (mixed, thermic Typic Ustipsamments) on upper slopes (Berg 1994).

The vegetation in the pastures was dominated by sand sagebrush and perennial warm-season grasses, including blue grama (Bouteloua gracilis [Willd. Ex Kunth] Lag. Ex Griffiths), sand dropseed (Sporobolus crytandrus [Torr.] A. Gray), sand bluestem (Andropogon hallii Hack.), little bluestem (Schizachyrium scoparium [Michx.] Nash), sand paspalum (Paspalum setaceum Michx.), and fall witchgrass (Digitaria cognata [Schult.] Pilg.). Cool-season grasses are limited to Texas bluegrass (Poa arachnifera Torr.) and annual grasses such as 6-wk fescue (Vulpia octoflora [Walter] Rydb.) and nonnative annual brome species (Bromus spp. L.). Abundant forbs included woolly plantain (Plantago patagonica Jacq.), western ragweed (Ambrosia psilostachya DC.), Indian blanket (Gaillardia pulchella Foug.), horsemint (Mentha spicata L.), buckwheat (Eriogonum spp. Michx.), and sunflower species (Helianthus spp. L.). Other shrubs present on the site include chickasaw plum (Prunus angustifolia Marsh.), and limited distributions of sumac species (Rhus spp. L.).

The study design consisted of 14 adjacent pastures ranging in size from 10-21 ha. Four pastures have not had any shrub control since 1939 (SAGE) and have likely never had any shrub control. Five pastures were treated with 2,4-D in May of 2003 (RECENT), and the remaining five were sprayed in 1984 (OLD). 2,4-D was sprayed at a rate of $1.0 \mathrm{~kg} \cdot \mathrm{ha}^{-1}$ with the use of a tractor-mounted boom sprayer. Herbicides were applied in May of each respective year. All pastures were grazed annually from January to August with mixed-breed stocker steers. Stocking rates were considered moderate based on previous work to determine appropriate stocking rates relative to the density of sagebrush and forage availability (Sims and Gillen 1999). SAGE pastures were stocked at 47 animal unit days (AUD) $\cdot \mathrm{ha}^{-1}$ and $69 \mathrm{AUD} \cdot \mathrm{ha}^{-1}$ in RECENT and OLD pastures. Stocking rates in pastures were maintained throughout the entire study period.

Vegetation transects were established in pastures systematically. Five strata were established lengthwise at equal distances across all pastures. Five sample points were established at regular intervals along each stratum for a total of 25 sample points per pasture. Sample points were marked permanently with paving stones and held in place with rebar. UTM coordinates were recorded for each sample point. At each sample point a 10-m transect was established and was used for multiple vegetation measures. The line-intercept method (Canfield 1941) was used for shrub cover and grass basal cover. Belt transects were established for sagebrush $(1 \times 10 \mathrm{~m})$ and forbs $(0.1 \times 10 \mathrm{~m})$ density. Sagebrush cover $(\%)$, sagebrush density 
(plants $\cdot \mathrm{m}^{-2}$ ), and forb density (plants $\cdot \mathrm{m}^{-2}$ ) were measured by species annually from 2003-2006. Forb species richness was derived by totaling the total number of forb species found in each belt transect. Vegetation sampling was conducted annually in June. Grass basal cover (\%) was recorded in 2003 and 2006. Visual obstruction measures (VO; cm of obstruction) were taken with the use of a Robel pole (Robel et al. 1970). VO sampling occurred at each permanent sampling point annually during the spring (May) and fall (October). Readings were taken from each cardinal direction at the height of $1 \mathrm{~m}, 4 \mathrm{~m}$ from the sampling point.

Grasshoppers (Orthoptera) were counted in $400.1-\mathrm{m}^{-2}$ circular plots in each pasture. Plot frames were distributed every 10 paces along a single transect located in the middle portion of each pasture. Plot frames were placed one day and grasshopper density was determined the next day by counting the number of grasshoppers flushed from each frame. Sampling took place over a 3-4-d period with the order of sampling among pastures randomized for each sampling period (Berry et al. 1996).

The data were analyzed with the use of an analysis of variance (ANOVA) with PROC GLIMMIX in SAS 9.2 (SAS 2005); there were three treatments (SAGE, OLD, and RECENT) with four, five, and five replicates, respectively. The Tukey-Kramer method was used for mean separations. Year was used as a random effect and treatment was a fixed effect. Year was used as a random factor to help account for the year-to-year variation because of precipitation differences (Loughin 2006). We divided all the variables into two categories, habitat structure and dietary resources. Habitat structure provides protective cover (thermal cover, escape cover, and nesting cover) for LPC throughout the year. We defined dietary resources as a broad category that includes forbs and grasshoppers that contribute to food for LPC. We further divided forbs into life-history strategies (annual or perennial) and identified specific forbs that were known to be important to LPC (Table 1). Treatment effects were analyzed on forb richness, total forb densities, perennial forbs, annual forbs, total LPC forbs, perennial LPC forbs, annual LPC forbs, and grasshopper density. Shrub density, shrub cover, VO, and grass basal cover were analyzed to determine impact of the treatments on habitat structure.

\section{RESULTS}

\section{Habitat Structure}

Habitat structure was reduced by 2,4-D. SAGE pastures had more VO in spring and fall than either OLD $(P<0.01$ and $P<0.01$, respectively) or RECENT pastures $(P<0.01$ and $P<0.01$, respectively). During the spring, OLD pastures had greater VO than RECENT pastures $(P<0.01)$, but did not differ in the fall $(P=0.40$; Table 2.) Spring VO was similar to fall VO in RECENT pastures $(P=0.64)$.

Sagebrush density and sagebrush cover were reduced by herbicide application $(P<0.01$ and $P<0.01$, respectively; Table 2). SAGE pastures had the highest density and cover of sand sagebrush compared to RECENT $(P<0.01$ and $P<0.1$, density and cover respectively) and OLD pastures $(P<0.01$ and $P<0.04$, respectively). OLD pastures had higher sage- brush density and cover than RECENT pastures $(P<0.01$ and $P<0.01$; Table 2).

There was an increase in grass basal cover with 2,4-D application. Grass cover in SAGE $(12 \% \pm 1.3 \mathrm{SE})$ pastures were less than RECENT $(16 \% \pm 1.4$ SE) and OLD $(15 \% \pm 1.3$ SE) pastures $(P<0.01$, and $P<0.01)$, respectively. OLD and RECENT pastures had similar amounts of grass cover $(P=0.36$; Table 2$)$.

\section{Dietary Resources}

Application of 2,4-D affected total forb abundance; total forb densities were higher in OLD pastures than SAGE pastures $(P=0.02)$. However, RECENT pastures did not show an increase in total forb density over SAGE pastures $(P=0.85$; Table 2). It appears that time since 2,4-D application is important because OLD pastures had more total forbs than RECENT pastures $(P=0.05)$. Application of $2,4-\mathrm{D}$ did not increase annual forb densities in RECENT pastures when compared to the SAGE pastures $(P=0.64)$. OLD pastures had more annual forbs than SAGE pastures $(P=0.01$; Table 2$)$. The application of 2,4-D treatments did not increase perennial forb densities; SAGE pastures had more perennial forbs than RECENT pastures $(P<0.01)$. However, with adequate recovery time following 2,4-D application, perennial forb densities were similar when compared to SAGE pastures $(P=0.14)$.

Total LPC forbs were most abundant in OLD pastures when compared to RECENT and SAGE pastures $(P<0.02$ and $P=0.04$, respectively; Table 2 ). RECENT pastures did not increase in total LPC forbs when compared to SAGE pastures $(P=0.44$; Table 2$)$. OLD pastures had more annual LPC forbs than RECENT $(P<0.04)$ and SAGE pastures $(P<0.01)$, whereas RECENT pastures did not have more annual LPC forbs than SAGE pastures $(P=0.39$; Table 2$)$. Perennial LPC forbs were scarce and thus reliable estimates were difficult to obtain (Table 2). Application of 2,4-D did not increase perennial LPC forbs $(P=0.09)$.

Application of 2,4-D did not increase forb species richness $(P=0.18$; Table 2). There were no differences in grasshopper densities across treatments $(P=0.6796$; Table 2$)$ regardless of increases in grass cover or forb abundance.

\section{DISCUSSION}

The objective of this research was to determine if controlling sand sagebrush with 2,4-D would increase dietary resources for LPC and to describe the changes in habitat structure (McIlvain and Savage 1949, Hagen et al. 2005). Our results indicate that annual forb density did increase in pastures treated with 2,4-D before 1985 (OLD pastures). There was not an increase in perennial forb densities in OLD or RECENT pastures. Furthermore, it is likely that 2,4-D may have limited perennial forb abundance and it may take several years for perennial forbs to recover. RECENT pastures did not have increases in annual forbs, suggesting that there may not be a short-term advantage to sand sagebrush control in terms of forb production. It appears that forbs only increased in treated pastures several years after 2,4-D application. This is likely because 2,4-D, a broadleaf herbicide, eliminated forbs for several years. It is important to emphasize that reduction of 
Table 1. Forb species found in lesser prairie-chicken (Tympanuchus pallidicinctus, LPC) diets. The table was compiled from several studies from multiple locations.

\begin{tabular}{|c|c|c|c|c|c|}
\hline Genus & Species & Common name & Life $^{1}$ & Part $^{2}$ & Reference $^{3}$ \\
\hline$\overline{\text { Achillea }}$ & millefolium & Yarrow & $p$ & $\mathrm{~V}$ & 6 \\
\hline Amaranthus & spp. & Pigweed & - & $\mathrm{s}$ & 1,6 \\
\hline Ambrosia & & Ragweed & $\mathrm{a}$ & $\mathrm{v}, \mathrm{s}$ & 4,6 \\
\hline Amphiachyris & spp. & Broomweed & $\mathrm{a}$ & $f$ & 6 \\
\hline \multirow[t]{2}{*}{ Artemisia } & caudata & Sagewort & $p$ & $\mathrm{v}$ & 3 \\
\hline & filifolia & Sand sagebrush & $p$ & v & 4,6 \\
\hline Atriplex & spp. & Saltbush & $p$ & v & 6 \\
\hline Bassia & scoparia & Firebush (burning bush) & $\mathrm{a}$ & v & 6 \\
\hline Capsella & bursa-pastoris & Shepherd's-purse & $\mathrm{a}$ & s & 6 \\
\hline Chamaesyce & fendleri & Fendler's sandmat & $\mathrm{p}$ & $\mathrm{v}, \mathrm{s}$ & $1,2,5$ \\
\hline Chenopodium & album & Lambsquarters & a & v & 6 \\
\hline Cleome & serrulata & Rocky mountain bee plant & $\mathrm{a}$ & v & 6 \\
\hline Commelina & erecta & Whitemouth dayflower & $p$ & v & 1,2 \\
\hline Convolvulus & spp. & Bindweed & $p$ & $\mathrm{~s}$ & 6 \\
\hline Croton & texensis & Texas croton & $\mathrm{a}$ & $\mathrm{v}, \mathrm{s}$ & 1 \\
\hline Cryptantha & cinerea & James' cryptantha & $p$ & v & 3 \\
\hline Cuscuta & spp. & Dodder & $p$ & $\mathrm{~s}$ & 6 \\
\hline Dalea & nana & Dwarf prairie clover & $p$ & - & 5 \\
\hline Dimorphocarpa & candicans & Palmer's spectaclepod & a & $v, s$ & 3,5 \\
\hline Ericameria & nauseiosus & Rubber rabbitbrush & $p$ & $\mathrm{v}$ & 2 \\
\hline Erigeron & modestus & Plains fleabane & $p$ & v & 3 \\
\hline Eriogonum & annuum & Annual buckwheat & a & $\mathrm{v}, \mathrm{s}$ & $1,2,3,4,5$ \\
\hline Evax & prolifera & Pygmy cudweed & $\mathrm{a}$ & - & 4 \\
\hline Evolvulus & nuttallianus & Shaggy dwarf morning- glory & $p$ & v & 3 \\
\hline Gaura & spp. & Beeblossom & $p$ & s & 1 \\
\hline Gutierrezia & sarothrae & Broom snakeweed & $p$ & $\mathrm{v}, \mathrm{s}$ & $2,4,5$ \\
\hline Helianthus & spp. & Sunflower & $p$ & $\mathrm{~s}$ & 1,6 \\
\hline Heterotheca & spp. & False goldenaster & $p$ & - & 3 \\
\hline Hymenoxys & spp. & Rubberweed & $p$ & - & 2,5 \\
\hline Ipomoea & leptophylla & Bush morning glory & $p$ & $b$ & 6 \\
\hline Krameria & spp. & Ratany & $p$ & v & 1,2 \\
\hline Linum & rigidum & Stiffstem flax & $p$ & $\mathrm{v}, \mathrm{s}$ & 1,3 \\
\hline Lepidium & oblongum & Veiny pepperweed & $p$ & - & 4 \\
\hline Lithospermum & incisum & Narrowleaf stoneseed & $p$ & $\mathrm{v}, \mathrm{s}$ & $2,3,4,5$ \\
\hline Oenothera & spp. & Evening primrose & $p$ & - & 2,5 \\
\hline Opuntia & spp. & Pricklypear & $p$ & $\mathrm{~s}$ & 3 \\
\hline Palafoxia & sphacelata & Othake & a & $\mathrm{v}, \mathrm{s}$ & 1 \\
\hline Penstemon & buckleyi & Buckley's beardtongue & $p$ & v & $2,3,5$ \\
\hline Phlox & spp. & Phlox & $p$ & v & 2,5 \\
\hline Physalis & spp & Ground cherry & $p$ & $\mathrm{v}, \mathrm{s}$ & 6 \\
\hline Plantago & spp. & Plantain & $\mathrm{a}$ & - & 4 \\
\hline Podophyllum & peltatum & Mayapple & $p$ & $f$ & 6 \\
\hline Polygala & alba & White milkwort & $p$ & v & 3 \\
\hline pomaria & jamesii & James' holdback & $p$ & $\mathrm{~s}$ & 1,3 \\
\hline Salsola & iberica & Prickly Russian thistle & $\mathrm{a}$ & v & 1,6 \\
\hline Senicio & sparatoides & Broom ragwort & $\mathrm{p}$ & - & 2,5 \\
\hline Silene & antirrhina & Sleepy silene & a & - & 4 \\
\hline Thelesperma & spp. & Greenthread & - & v & 1,3 \\
\hline Townsendia & exscapa & Stemless Townsend daisy & $p$ & v & 3 \\
\hline Tradescantia & occidentalis & Prairie spiderwort & $p$ & - & 4 \\
\hline Verbena & spp. & Vervain & $p$ & $v$ & 2 \\
\hline Viola & kitaibeliana & Field pansy & a & - & 4 \\
\hline
\end{tabular}

${ }^{1}$ Life-history strategy: annual forbs (a), and perennial forbs (p).

${ }^{2}$ Parts of the plant that were consumed by lesser prairie-chickens: vegetation $(v)$, seed $(s)$, and flowers or buds (f).

${ }^{3}$ References: 1, Crawford and Bolen (1976); 2, Davis et al. (1980); 3, Doer and Guthery (1983); 4, Jones (1963); 5, Riley et al. (1993); 6, Schwilling (1955). 
shrubs did increase basal grass cover and increase annual forbs; however, this did not lead to increases in forb richness or grasshopper abundance (Gunter et al. 2012). These conclusions indicate that potential improvements to LPC habitat following 2,4-D application are limited. Conversely, Donaldson (1969) suggested that there were more LPC in areas that had been treated with 2,4-D, because more forbs were present in the treated areas. However, Donaldson did not give the details of the length of time since 2,4-D application, thus making comparisons to our study difficult.

Although our results suggest that there were increases in grasses and annual forbs following 2,4-D application, other factors must be considered before implementing shrub-control projects. Shrub cover is vital for broods, nesting hens, and adult survival (Riley et al. 1992; Hagen et al. 2005; Patten et al. 2005; Fields et al. 2006; Pitman et al. 2006; Hagen et al. 2007; Patten and Kelly 2010). Therefore, managers must ascertain whether there is sufficient protective cover and whether dietary resources are limiting LPC productivity prior to project implementation. Even though the OLD pastures had more habitat structure than RECENT pastures, it is unlikely that they have adequate protective cover to support brooding and nesting or provide adequate thermal cover. It has been suggested that LPC nesting hens need sagebrush densities greater than 5000 plants $\cdot \mathrm{ha}^{-1}$ (Giesen 1994; Hagen et al. 2004; Pitman et al. 2005). 2,4-D suppressed sagebrush densities below 5000 plants $\cdot \mathrm{ha}^{-1}$ for more than 20 years (2000 plants $\cdot \mathrm{ha}^{-1}$ in OLD pastures). LPC broods typically use areas with sagebrush densities around 4000 plants $\cdot \mathrm{ha}^{-1}$ or $20 \%$ canopy cover (Hagen et al. 2004; Fields et al. 2006). None of the treated pastures in our study approach this density or cover of sand sagebrush. OLD pastures had 2000 plants $\cdot \mathrm{ha}^{-1}$, which is half of the needed shrub cover for brooding LPC; SAGE pastures had 5700 plants $\cdot$ ha $^{-1}$. Shrub cover is also essential for adult LPC survival. Survival was higher for LPC using sites with shrub cover greater than $20 \%$ (Patten et al. 2005; Hagen et al. 2007). When comparing the results of our study to previous research, only the SAGE pastures provided adequate protective cover for brooding, nesting, and adult survival. Thus, managers must assure that they have adequate cover before proceeding with shrub-control measures. If herbicide is applied, it should be applied in narrow strips or small patches in order to ensure adequate habitat structure is available (Dahlgren et al. 2006).

Success of management practices such as application of 2,4$\mathrm{D}$ are temporally and spatially dependent. Research has shown that LPC populations decline where shrub cover was lost at landscape levels (Jackson and DeArment 1963; Crawford 1980; Patten et al. 2005). However, Donaldson (1969) observed increased LPC abundance in areas treated with 2,4$\mathrm{D}$ presumably due to an increase in forb abundance. These findings suggest that large-scale removal of shrubs is detrimental to LPC populations while some small scale $(<250 \mathrm{ha})$ reductions in shrubs may increase LPC use of the treated areas (Donaldson 1969). Furthermore, there is a temporal aspect of sand sagebrush control when using 2,4-D. RECENT pastures did not increase in dietary resources (forbs or grasshoppers); however, OLD pastures had greater annual forb abundance. Thus, it may take several years for the increase of annual forbs to occur. Our study was conducted at relatively small scale
Table 2. Lesser prairie-chicken (Tympanuchus pallidicinctus) habitat structure and food base measures after sand sagebrush (Artemisia filifolia) control in northwestern Oklahoma. RECENT pastures were treated in 2003 ( $<5$ yr posttreatment), OLD pastures have not been treated since 1984 , and SAGE pastures have not been treated. Statistical differences between treatments are indicated by lower-case letters.

\begin{tabular}{|c|c|c|c|}
\hline & RECENT & OLD & SAGE \\
\hline \multicolumn{4}{|l|}{ Dietary resources } \\
\hline \multicolumn{4}{|l|}{ Forb density ${ }^{1}$} \\
\hline Total & $59 \pm 22^{\mathrm{a}}$ & $81 \pm 30^{b}$ & $55 \pm 20^{\mathrm{a}}$ \\
\hline Annual & $53 \pm 22^{\mathrm{a}}$ & $75 \pm 31^{b}$ & $46 \pm 19^{a}$ \\
\hline Perennial & $4.0 \pm 0.84^{a}$ & $4.0 \pm 0.84^{a, b}$ & $6.2 \pm 0.92^{b}$ \\
\hline Forb richness ${ }^{2}$ & $5.5 \pm 0.97^{a}$ & $6.0 \pm 1.1^{\mathrm{a}}$ & $5.3 \pm 0.93^{\mathrm{a}}$ \\
\hline \multicolumn{4}{|l|}{ LPC-forb ${ }^{3}$ density ${ }^{1}$} \\
\hline Total & $40 \pm 12^{\mathrm{a}}$ & $65 \pm 19^{b}$ & $32 \pm 9.8^{\mathrm{a}}$ \\
\hline Annuals & $40 \pm 12^{\mathrm{a}}$ & $63 \pm 19^{b}$ & $30 \pm 9.5^{\mathrm{a}}$ \\
\hline Perennial & $0.70 \pm 0.18^{\mathrm{a}}$ & $1.3 \pm 0.34^{\mathrm{a}}$ & $1.3 \pm 0.37^{\mathrm{a}}$ \\
\hline \multicolumn{4}{|l|}{ Grasshoppers } \\
\hline Density ${ }^{4}$ & $4.5 \pm 0.84^{\mathrm{a}}$ & $4.3 \pm 0.72^{\mathrm{a}}$ & $4.4 \pm 0.77^{\mathrm{a}}$ \\
\hline \multicolumn{4}{|l|}{ Habitat structure } \\
\hline \multicolumn{4}{|l|}{ Visual obstruction ${ }^{5}$} \\
\hline Total & $7.33 \pm 0.16^{\mathrm{a}}$ & $9.17 \pm 0.20^{b}$ & $16.9 \pm 0.41^{\mathrm{c}}$ \\
\hline Spring & $7.28 \pm 0.21^{\mathrm{a}}$ & $10.14 \pm 0.29^{b}$ & $18.97 \pm 0.60^{\circ}$ \\
\hline fall & $7.37 \pm 0.24^{\mathrm{a}}$ & $8.28 \pm 0.27^{\mathrm{a}}$ & $15.04 \pm 0.56^{b}$ \\
\hline \multicolumn{4}{|l|}{ Sand sagebrush } \\
\hline Density ${ }^{1}$ & $0.14 \pm 0.02^{\mathrm{a}}$ & $0.20 \pm 0.02^{b}$ & $0.57 \pm 0.02^{c}$ \\
\hline$\%$ canopy cover & $4.4 \pm 0.57^{\mathrm{a}}$ & $10 \pm 1.6^{\mathrm{b}}$ & $26 \pm 8.3^{\mathrm{c}}$ \\
\hline
\end{tabular}

${ }^{1}$ Plants $\cdot \mathrm{m}^{-2}$.

${ }^{2}$ Number of forb species $\cdot \mathrm{m}^{-2}$.

${ }^{3}$ Lesser prairie-chicken forbs compiled from literature.

${ }^{4}$ Grasshoppers $\cdot \mathrm{m}^{-2}$.

${ }^{5}$ Centimeters of vertical obstruction.

(pasture level 10-20 ha), and thus inference to LPC habitat at the landscape scale may be limited.

Application of 2,4-D reduced protective cover for at least two decades and the annual forb response takes several years to realize. Therefore, managers must be able to identify proper scale of management and timing of treatments in order to ensure that they are advantageous for LPC. Hagen et al. (2004) suggests that if herbicides are used, they should not reduce shrub cover to less than $25 \%$. However, there is little evidence reducing sagebrush stands to $25 \%$ cover will increase forbs. Sagebrush cover in RECENT and OLD pastures was reduced below $25 \%$ cover and a positive annual forb response took several years to realize. However, Donaldson showed an overall increase of forbs in treated areas, but his results do not indicate whether the increase was due to annual or perennials, his results only span 1 year and he does not give any indication as to the time since treatment. Therefore, the results from Donaldson's study may not be a valid comparison to our study. The density of sagebrush observed in untreated (SAGE) pastures $\left(0.56\right.$ plants $\left.\cdot \mathrm{m}^{-1}\right)$ is similar to densities reported by Donaldson (1969), Pitman et al. (2005), and Winter et al. (2011a): 0.39 plants $\cdot \mathrm{m}^{-1}, 0.65$ plants $\cdot \mathrm{m}^{-1}$ and 0.60 plants $\cdot \mathrm{m}^{-1}$, respectively). However, some areas within the range of sand sagebrush do not have as much sagebrush, so it is uncertain how these communities might respond to 2,4-D treatments (Sims et al. 1976) Research is needed to identify 
adequate levels of sagebrush control that will balance protective cover with increases in forb densities (Thacker 2010).

The application of 2,4-D did increase stocker gain $\cdot \mathrm{ha}^{-1}$ and grass cover (Gunter et al. 2012). Even though stocking rates were adjusted based upon available forage, there appears to be no influence of stocking rates on forb production. In the RECENT pastures annual forbs were not different from SAGE pastures, indicating that an adjustment of stocking rates did not increase forbs. If there was an influence from grazing it would be anticipated that there would either be fewer forbs or that the disturbance from the grazing increased the number of forbs. There is no consistent pattern to indicate that stocking rate confounded our results.

The lack of stable LPC populations on our study site precluded us from evaluating the direct effects of sagebrush control on LPC. This would have helped clarify whether the increase in annual forbs would actually benefit LPC productivity and survival. Some have been able to associate increased numbers of grouse using habitat treatments as a measure of habitat management effectiveness (Dahlgren et al. 2006; Thacker 2010), but these studies were not able to link increased use to improved survival or increases in grouse reproduction. Future research should focus on connecting management activities to LPC productivity and population responses. If the objective is to improve LPC populations, management needs to focus on improvement of nesting and brooding habitat (Hagen et al. 2004; Pitman et al. 2006). Although our study showed increases in annual forb abundance, further research is needed to determine if increased annual forb abundance improves LPC productivity. Additional research should also focus on experiments that use lower application rates and different application timing in order to reduce short-term negative impacts of 2,4-D on forbs while providing reduction in sand sagebrush densities. It would also be useful for research to identify optimal levels of sand sagebrush control needed in order to provide adequate protective cover (shrubs) and dietary resources. Dahlgren et al. (2006) recommended that treatments should be kept relatively small and narrow. Their data suggests that sage-grouse use of the treated areas occurred within $30 \mathrm{~m}$ of the edge. This approach may be a good starting point for shrub treatments within the LPC range. Other research should also focus on use of other selective herbicides. Dahlgren et al. (2006) reports that tebuthiuron was effective because it reduced shrub cover and increased forb abundance immediately and increased the number of grouse broods using the sprayed plots. Application of light rates of tebuthiuron may be a viable herbicide treatment to use because it will effectively remove shrubs without reducing forb abundance.

\section{IMPLICATIONS}

The use of 2,4-D resulted in long-term suppression of sand sagebrush abundance with limited increases in forb abundance and had no impact on grasshopper abundance. We caution against the use of 2,4-D for LPC habitat management until further research can document its impacts on LPC productivity. Fire may be a feasible alternative that will reduce sagebrush canopy cover and increase forb standing crop (Vermeire 2002).
However, Winter et al. (2011b) reported that burning did not increase forb canopy cover. Before managers implement shrub management, they should first assess what factors are limiting LPC populations. If nesting cover is limited, shrub control may not be appropriate because the increase in grass abundance will not compensate for the loss of shrub cover. The only situation under which these treatments may be appropriate is when dietary resources are limiting. Therefore, before managers implement 2,4-D treatments, management objectives must be clearly defined by identifying the limiting factor for a specific LPC population. Then managers must determine if a delayed increase in annual forbs will meet their management objectives.

\section{LITERATURE CITED}

Allred, B. W. 1949. Distribution and control of several woody plants in Texas and Oklahoma. Journal of Range Management 2:17-29.

Beck, J. L., AND D. L. Mitchell. 2000. Influences of livestock grazing on sage-grouse habitat. Wildlife Society Bulletin 28:993-1002.

Bell, A. L., S. D. Fuhlendorf, M. A. Patten, D. H. Wolfe, and S. K. Sherrod. 2010. Lesser prairie-chicken hen and brood habitat use on sand shinnery oak. Rangeland Ecology and Management 63:478-486.

BERG, W. A. 1994. Sand sagebrush-mixed prairies. In: T. N. Shiflet [ED.]. Rangeland cover types of the United States. Denver, CO, USA: Society for Range Management. p. 99.

Berry, J. S., A. A. Onsager, W. P. Kemp, K. T. McNary, J. Larsen, J. A. Lockwood, AND R. N. Foster. 1996. Assessing rangeland grasshopper populations. In: G. L. Cunningham and M. W. Sampson [TECH. EDS.]. Grasshopper integrated pest management user handbook. Washington DC, USA: USDA Animal and Plant Health Inspection Service. Technical Bulletin 1809. p. 1-12.

Canfield, R. 1941. Application of line interception in sampling range vegetation. Journal of Forestry 39:388-394.

Cannon, R. W., and F. L. Knopf. 1981. Lesser prairie-chicken densities on shinnery oak and sand sagebrush rangelands in Oklahoma. Journal of Wildlife Management 45:521-524.

Copelin, F. F. 1963. The lesser prairie-chicken in Oklahoma. Oklahoma City, OK, USA: Oklahoma Wildlife Conservation Department. Technical Bulletin 6. 58 p.

Crawford, J. A. 1980. Status, problems, and research needs of lesser prairiechickens. In P. A. Vohs and F. L. Knopf [EDS.]. Proceedings Prairie Grouse Symposium; Stillwater, OK, USA: Oklahoma State University. p. 1-7

Crawford, J. A., and E. G. Bolen. 1976. Effects of land use on lesser prairie-chickens in Texas. Journal of Wildlife Management 40:96-104.

Dahlgren, D. K., R. Chi, and T. Messmer. 2006. Greater sage-grouse response to sagebrush management in Utah. Wildlife Society Bulletin 34:975-985.

Davis, C. A., T. Z. Riley, R. A. Smith, And M. J. Wisdom. 1980. Spring-summer foods of lesser prairie-chickens in New Mexico. In: P. A. Vohs and F. L. Knopf [EDs.]. Proceedings of the Prairie Grouse Symposium; 17-18 September 1980; Stillwater, OK, USA: Oklahoma State University. p. 75-80.

Doer, T. B., AND F. S. GUthery. 1983. Effects of tebuthiuron on lesser prairie-chicken habitat and foods. Journal of Wildlife Management 47:1138-1142.

DonaLDSON, D. D. 1969. Effect on lesser prairie-chicken of brush control in western Oklahoma [dissertation]. Stillwater, OK, USA: Oklahoma State University. $70 \mathrm{p}$.

Fields, T. L., G. C. White, W. C. Gllbert, and R. D. Rodgers. 2006. Nest and brood survival of lesser prairie-chickens in west central Kansas. Journal of Wildlife Management 70:931-938.

Fuhlendorf, S. D., A. J. W. Woodward, D. M. LesLle, JR., and J. S. Shackford. 2002. Multi-scale effects of habitat loss and fragmentation on lesser-prairie chicken populations in the US Great Plains. Landscape Ecology 17:617-628.

GIESEN, K. M. 1994. Movements and nesting habits of lesser prairies chicken hens in Colorado. The Southwestern Naturalist 39:96-98.

Gunter, S. A., E. T. Thacker, T. L. Springer, and R. D. Jones. 2012. Effects of sand sagebrush control in southern mixed prairie rangeland on cattle performance and economic return. The Professional Animal Scientist 28:204-212. 
Hagen, C. A., And K. M. Giesen. 2005. Lesser prairie-chicken (Tympanuchus pallidicinctus). In: A. Poole [ED.]. The birds of North America online. Ithaca, NY, USA: Cornell Lab of Ornithology. Available at: http://bna.birds.cornell.edu/review/ species/364/articles/introduction. Accessed 29 August 2011.

Hagen, C. A., B. E. Jamison, K. M. Giesen, and T. Z. Riley. 2004. Guidelines for managing lesser prairie-chicken populations and their habitats. Wildlife Society Bulletin 32:69-82.

Hagen, C. A., J. C. Pitman, B. K. Sandercock, R. J. Robel, and R. D. Applegate. 2007. Age-specific and probable causes of mortality in female lesser prairie-chickens. The Journal of Wildlife Management 71:518-525.

Hagen, C. A., G. C. Salter, J. C. Pitman, R. J. Robel, and R. D. Applegate. 2005. Lesser prairie-chicken brood habitat in sand sagebrush: invertebrate biomass and vegetation. Wildlife Society Bulletin 33:1080-1091.

Hamerstrom, F. N., and F. Hamerstrom. 1961. Status and problems of North American grouse. Wilson Bulletin 73:284-294.

Jackson, A. S., and R. DeArment. 1963. The lesser prairie-chicken in the Texas panhandle. Journal of Wildlife Management 27:733-737.

JonES, R. E. 1963. Identification and analysis of lesser and greater prairie chicken habitat. Journal of Wildlife Management 27:757-778.

LoUGHIN, T. M. 2006. Improved experimental design and analysis for long-term experiments. Crop Science 46:2492-2502.

Mclıvain, E. H., AND D. A. SAVAGE. 1949. Spraying 2,4-D by airplane on sand sagebrush and other plants of the southern Great Plains. Journal of Range Management 2:43-52.

Mcllvain, E. H., and D. A. Savage. 1954. Progress in range management. In: A. G. Norman [ED.]. Advances in agronomy. Vol. VI. New York, NY, USA: Academic Press. p. 1-65.

Mote, K. D., R. D. Applegate, J. A. Balley, K. E. Giesen, R. Horton, and J. L. Sheppard. 1999. Assessment and conservation strategy for lesser prairies chicken (Tympanuchus pallidicinctus). Emporia, Kansas, USA: Kansas Department of Wildlife and Parks. $27 \mathrm{p}$.

Patten, M. A., and J. F. Kelly. 2010. Habitat selection and the perceptual trap. Ecological Applications 20:2148-2156.

Patten, M. A., D. H. Wolfe, E. Shochat, and S. K. Sherrod. 2005. Effects of microhabitat and microclimate selection on adult survivorship of the lesser prairie-chicken. Journal of Wildlife Management 69:1270-1278.

Pitman, J. C., C. A. Hagen, B. E. Jamison, R. J. Robel, T. M. Loughin, and R. D. Applegate. 2006. Survival of juvenile lesser prairie-chickens in Kansas. Wildlife Society Bulletin 34:675-681.

Pitman, J. C., C. A. Hagen, R. J. Robel, T. M. Loughin, and R. D. Applegate. 2005. Location and success of lesser prairie-chicken nests in relation to vegetation and human disturbance. Journal of Wildlife Management 69:1259-1269.
Riley, T. Z., C. A. Davis, M. ORtiz, and M. J. Wisdom. 1992. Vegetative characteristics of successful and unsuccessful nests of lesser prairie-chicken. Journal of Wildlife Management 56:383-387.

Riley, T. Z., C. A. Davis, And R. A. Smith. 1993. Autumn and winter foods of lesser prairie-chicken (Tympanuchus pallidicinctus) (Galliformes: Tetraonidae). Great Basin Naturalist 53:186-189.

RobB, L. A., AND M. A. Schroeder. 2005. Lesser prairie-chicken (Tympanuchus pallidicinctus): a technical conservation assessment. USDA Forest Service Rocky Mountain Region. Available at: http://www.fs.fed.us/r2/projects/scp/ assessments/lesserprairiechicken.pdf. Accessed 17 May 2010.

Robel, R. J., J. N. Briggs, A. D. Dayton, and L. C. Hulbert. 1970. Relationships between visual obstruction and weight of grassland vegetation. Journal of Range Management 23:295-297.

SAS Institute, Inc. 2005. Version 9.2. Carey, North Carolina, USA: SAS Institute.

SCHWILLING, M. D. 1955. A study of lesser prairie chickens in Kansas. Emporia, KS, USA: Forestry Fish and Game Commission. 51 p.

Sims, P. L., B. E. Dahl, and A. H. Denham. 1976. Vegetation and livestock response at three grazing intensities on sandhill rangeland in eastern Colorado. Fort Collins, CO, USA: Colorado Agricultural Experiment Station. Tech Bulletin 190. $130 \mathrm{p}$.

Sims, P. L., And R. L. GILLEN. 1999. Rangeland and steer response to grazing in the southern plains. Journal of Range Management 52:651-660.

TAYLoR, M. A., AND F. S. GutheRY. 1980. Fall-winter movements, ranges and habitat use of lesser prairie-chickens. Journal of Wildlife Management 44:521-524.

THACKER, E. T. 2010. Greater sage-grouse seasonal ecology and response to habitat manipulations in northern Utah [dissertation]. Logan, UT, USA: Utah State University. 124 p.

Valentine, J. F. 1980. Range development and improvements. Provo, UT, USA: Brigham Young University Press. $545 p$.

Vermeire, L. T. 2002. The fire ecology of sand sagebrush-mixed prairie in the Southern Great Plains [dissertation]. Lubbock, TX, USA: Texas Tech University. $98 \mathrm{p}$.

Winter, S. L., S. D. Fuhlendorf, C. L. Goad, C. A. Davis, K. R. Hickman, and D. M. Leslie. 2011a. Fire tolerance of a resprouting Artemisia (Asteraceae) shrub. Plant Ecology 212:2085-2094.

Winter, S. L., S. D. Fuhlendorf, C. L. Goad, C. A. Davis, K. R. Hickman, and D. M. Leslie. 2011b. Restoration of the fire-grazing interaction in Artemisia fillifolia shrubland. Journal of Applied Ecology 49:242-250.

Woodward, A. J., S. D. Fuhlendorf, D. M. Leslie, JR., and J. Shackford. 2001. Influence of landscape composition and change on lesser prairie-chicken (Tympanuchus pallidicinctus) populations. American Midland Naturalist 145:261-274. 